\title{
ASPECT USE IN SLAVIC INFINITIVES AND CORRESPONDING DA-CONSTRUCTIONS
}

\author{
SILJE SUSANNE ALVESTAD \\ University of Oslo
}

\section{A B S T R AC T}

In Dickey (2000), the most comprehensive comparative account of aspect use in Slavic to date, ten Slavic languages are considered based on seven parameters of use, but two important verb forms are not accounted for: the imperative and the infinitive. The imperative was dealt with in Benacchio (2010), von Waldenfels (2012), and Alvestad (2013). Now it is time the infinitive receives its fair share of attention too. Thus, in a larger project I compare how aspect is used in the infinitive in Russian, Ukrainian, Belarusian, Polish, Upper Sorbian, Czech, Slovak, Serbian, Croatian and Slovene and in the corresponding $d a$-constructions in Bulgarian and Macedonian (and Serbian, Croatian and Slovene) based on a study of several parallel-annotated novels in the ParaSol corpus. Against the background of existing literature, one hypothesis could be that (i) in the infinitive, the freedom of choice is significant as far as aspect use is concerned (see, e.g. Galton (1976)), and (ii) the East-West divide in aspect use can be observed in the infinitive too. My initial findings, however, which are from Russian and Croatian and presented in this paper, suggest that (i) must be rejected and (ii) must be modified; in East Slavic, the perfective aspect is far more widespread in the infinitive than in the other verb forms. From this starting point I outline, towards the end of the article, how we can proceed to be able to account for the findings within a formal theoretical framework. The picture of how aspect is used in the Slavic languages is not complete until infinitives, and the corresponding $d a$-constructions, are accounted for.

\section{[1] INTRODUCTION}

The starting point of this paper is a glaring gap in comparative Slavic aspectology - namely, that represented by the infinitive verb form. In Dickey (2000), the most comprehensive comparative account of aspect use in Slavic to date, ten Slavic languages are investigated based on seven types of contexts of use, but two important verb forms are not accounted for: the imperative and the infinitive. The imperative was dealt with in Benacchio (2010), von Waldenfels (2012) and, more recently, Alvestad (2013). As far as the infinitive is concerned, there are the works of Dobrušina (2012), Fortuin $(2000,2007)$, Israeli $(2013,2014)$, and Wiemer (2001), 
but they concern mostly Russian ${ }^{1}$ and only certain subsets of uses of infinitives. Thus, it is time the infinitive too receives its fair share of attention within comparative Slavic aspectology. To take a few steps towards this goal is one of the aims of this paper. In a more comprehensive project I conduct a corpus-based comparative investigation of how aspect is used in Slavic infinitives (and corresponding $\mathrm{da}$-constructions), taking the following 12 modern Slavic languages into consideration: Russian (RU), Ukrainian (UK), Belarusian (BY), Polish (PL), Upper Sorbian (us), Czech (cz), Slovak (sк), Bulgarian (вG), Macedonian (мк), Serbian (sR), Croatian (HR), and Slovene (SN). Consider (1) below, where, first, the Russian original is presented followed by its associated translation in the other Slavic languages. ${ }^{2}$
a. RUSSIAN
Ты говоришь, товарищ Ермаченко, что здесь надо будет драться, а я думаю - надо утром отходить. ${ }^{\mathrm{IPF}}$
'Comrade Ermačenko, you are saying that we will have to fight here, but I think that it's necessary to leave in the morning.' (ParaSol. Os- trovskij, Kak zakaljalas' stal', henceforth Kzs)

b. BELARUSian
(...) тут трэба будзе біцца, а я думаю - трэба раніцай адыходзіц̧ь. ${ }^{\mathrm{IPF}}$
c. UKRAINIAN
(...) тут треба буде битись, а я гадаю - треба вранці відходити. ${ }^{\mathrm{IPF}}$

d. Polish

(...) że tu trzeba się będzie bić, a ja sądzę - że trzeba się będzie rano wycofać. ${ }^{\mathrm{PF}}$

e. SERBIAN

f. CRoAtian
(...) da bi se ovde trebalo tući, a ja mislim da ujutru treba otići. ${ }^{\mathrm{PF}}$

(...) da bi se ovdje imalo boriti. A ja mislim da ujutro treba otići. ${ }^{\mathrm{PF}}$

g. UPPER SORBIAN
(...) tule do bitwy hić, ja pak sej myslu, zo dyrbimy jutře wottud woteńć. ${ }^{\mathrm{PF}}$

h. SLOVAK

i. $\mathrm{CZECH}$
(...) že sa tu bude treba bit', ale ja si myslím, že by sme ráno mali odíst. ${ }^{\mathrm{PF}}$
(...) že tu budeme musit bojovat, ale já myslím, že musíme zítra ráno odejít. $^{\mathrm{PF}}$

j. Slovene
(...) da se bo treba tukaj udariti, jaz pa mislim, da moramo zjutraj od- riniti. $^{\mathrm{PF}}$

\footnotetext{
${ }^{1}$ Dobrušina $(2012)$, Fortuin $(2000,2007)$ and Israeli $(2013,2014)$ concern Russian only, while Wiemer $(2001)$ includes Polish in addition to Russian.

${ }^{2}$ This and all subsequent examples are from the ParaSol corpus, http://www.slavist.de/, cf. von Waldenfels (2006). In the English translation of (1), (2), (3), and (6), I have consulted Prokofeva (1959).
} 
I have included MK and BG in the investigation and so will have to be concerned with $d a$-constructions as well. Specifically, MK does not have infinitives, and BG only has a short form of the infinitive that has a very restricted use, cf. e.g. Mišeska-Tomić (2006, 456-7). The form both languages use instead is the daconstruction - the complementizer da (cf. e.g. Mišeska-Tomić (2006), Todorović (2012)) + a present tense verb form - as seen in (2) below.
a. MACEDONIAN
(...) а јас мислам - утре треба да си одиме. ${ }^{\mathrm{PF}}$
b. Bulgarian
(...) а пък аз мисля, че утре сутрин трябва да отстъпим. ${ }^{\mathrm{PF}}$

Moreover, in some Slavic languages, the infinitive and the da-construction appear to compete for distribution. This is the case, to some extent, in SN, to a higher degree in HR, and to a significant degree in SR. Against the background of this observation and examples such as (1) and (2), three questions arise that need to be answered. First, how is aspect used in Slavic infinitives and da-constructions? Second, what are the semantic similarities and differences between infinitives and da-constructions? Third, if the infinitive and the da-construction indeed compete in certain Slavic languages, what are the decisive factors in this rivalry? In this paper I will seek to bring us closer to the answer to the first question. In the final section I will outline how we can proceed to find the answers to questions two and three.

\section{[2] MOTIVATION AND BACKGROUND}

As mentioned above, infinitives are one of the very few verb forms that have so far not been accounted for in comparative Slavic aspectology. In addition, the infinitive verb form is frequently ignored and poorly understood in formal theoretical linguistics too. The question of the semantics of infinitives, for example, is far from settled. One question concerns infinitives and tense. Stowell (1982) was among the first to point out that infinitives may still encode tense syntactically or semantically at the level of logical form even though they lack tense morphology. This view has gained ground within certain schools of thought in the last three decades but it has also been challenged (see e.g. Wurmbrand (2014)). Since verbal aspect is obligatorily present in all slavic infinitives, and based on the assumption that aspects are relations between times - specifically, between event times and their reference times, cf. Klein (1995) - a study of aspect use in Slavic infinitives will shed light on the question of infinitives, time and tense too.

Moreover, some of the $d a$-constructions under investigation may be subjunctives, but studies of the semantics of infinitives rarely compare this verb form with the subjunctive. The only exception I am aware of is Han (1998), who also includes 
the imperative. Han, however, does not take verbal aspect into account. However, as exemplified in (3) below, in one and the same context, we see that some Slavic languages use the infinitive (italicized), some use the imperative (underlined), and some use da-constructions that should be characterized as subjunctives (also underlined). The numerous examples of this kind suggest that there are semantic and/or pragmatic similarities between not only the infinitive and the subjunctive, on the one hand, but also the imperative, on the other hand. A study of Slavic infinitives such as the abovementioned larger project will shed light on this issue too.

a. RUSSIAN

- Никого из зала не выпускать, ${ }^{\mathrm{IPF}}$ nоставить ${ }^{\mathrm{PF}}$ часовых, приказал он.

"'Do not let anyone out of the hall, call out the guards!" he ordered.' (ParaSol. Ostrovskij, Kzs)

b. BELARUSIAN

- Нікога з зала не выпускац̧ь, ${ }^{\mathrm{IPF}}$ nаставіu̧ь ${ }^{\mathrm{PF}}$ вартавых, загадаў ён.

c. UKRAINIAN

- Нікого з зали не випускатu, ${ }^{\mathrm{IPF}}$ поставитu ${ }^{\mathrm{PF}}$ вартових!

d. Polish

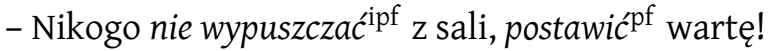

e. SERBIAN

- Ne puštati ${ }^{\mathrm{ipf}}$ nikoga iz sale, postavi ${ }^{\mathrm{pf}}$ stražu, naredi on.

f. CROATIAN

- Ne puštati ${ }^{\text {ipf }}$ nikoga iz dvorane, postavitipf stražu, naredi on.

g. UPPER SORBIAN

- Nikoho ze žurle njepušćće, ipf nastajće ${ }^{\text {pf }}$ straže, přikaza.

h. SLOVAK

- 'Stráže ku vchodu! Nikoho nepustitpf zo sály!' rozkázal.

i. $\mathrm{CZECH}$

- Nikoho ze sálu nepustit, ${ }^{\mathrm{pf}}$ postavit ${ }^{\mathrm{pf}}$ stráže!' nařídil.

j. SLOVENE

- 'Nikogar mi ne spuščajtepf iz dvorane,' je ukazal. 'Stražo postavite!'pf

k. BULGARIAN

- Никой да не напуска ${ }^{\mathrm{IPF}}$ салона, да се поставят ${ }^{\mathrm{PF}}$ часовои - заповяда той.

1. MACEDONIAN

- Никој да не се пушта ${ }^{\mathrm{IPF}}$ од салата, да се постават ${ }^{\mathrm{PF}}$ стражари, - нареди тој.

In (3), as we can see, RU, BY, UK, PL, HR, SK, and CZ use infinitives, Us and SN use imperatives, SR uses one infinitive and one imperative, and BG and MK use daconstructions that should be characterized as subjunctives. 
[3] State of ThE ART, PROBLEMS, HYPOTHESES, AND PRELIMINARY RESULTS

The first problem that has to be solved can be stated as follows. Problem 1: How is aspect used in Slavic infinitives? In his study from 2000, Dickey concludes that aspect use in Slavic varies geographically, in the sense that IPF is the most widely used aspect in East Slavic and PF is the most frequently used aspect in West Slavic. As far as imperatives are concerned, Benacchio's (2010), von Waldenfels's (2012) and Alvestad's (2013) results corroborate the East-West divide, although with some modifications. The share of IPF forms as a percentage of the total number of non-negated imperatives ${ }^{3}$ investigated in Alvestad (2013) is as follows for each of the languages under investigation: RU $(60 \%)>$ BY $(59 \%)>$ UK $(58 \%)>$ BG $(48 \%)>$ PL $(47 \%)>$ SR, HR $(45 \%)>$ MK $(44 \%)>$ US $(43 \%)>$ SK $(33 \%)>$ CZ $(31 \%)>$ SN (29\%). Against this background, a plausible hypothesis with regard to Problem 1 can be stated thus.

Hypothesis 1: The East-West divide can be observed in infinitives as well: the East Slavic languages - RU, BY, and UK - constitute an IPF-oriented group of languages, while the West Slavic languages $-\mathrm{SK}, \mathrm{CZ}$, and $\mathrm{SN}-$ make up a PF-oriented group.

In order to bring us closer to a solution to Problem 1 I have made use of the ParaSol corpus, cf. von Waldenfels (2006). ParaSol is the most comprehensive parallel corpus of Slavic languages to date. I took RU as my starting point, since RU is that language which is represented by the highest number of tokens: 3.64 million (as of March 2017). For reasons that will become clear below, I only take telic predicates into consideration, i.e. accomplishments and achievements, cf. Vendler (1957).

Examples such as (1) and (2) support HYPOTHESIS 1: IPF is used in RU, BY, UK, and PL while PF is used in SR, HR, US, SK, CZ, and SN. Still, ProBlem 1 must be addressed. Based on (1) and (2) it would seem that the use of aspect in the infinitive is almost identical to that in the imperative, but my survey suggests that this is not the case. The East Slavic languages use PF significantly more often in infinitives than in the imperative, for example. (4) below is a representative example. ${ }^{4,5}$

(4) a. RUSSIAN

Так ты думаешь, я не знаю, кто мог сделать ${ }^{\mathrm{pf}}$ такую подлость - ис-

${ }^{3}$ Alvestad (2013) follows Kaufmann (2012) and takes an imperative to be a pair of a particular kind of form (second person singular or second person plural) and one out of a particular set of functions (request, command, permission, invitation, etc.). For Russian more than 350 imperatives were investigated.

${ }^{4}$ The Polish translation of Kzs is currently (i.e. as of end of March, 2017) unavailable in ParaSol.

${ }^{5} \mathrm{As}$ one of the reviewers correctly points out, the principles governing the use of aspect in the infinitives and $d a$-constructions in cases such as (4), in which the verb forms are within the scope of a modal predicate, are not necessarily identical to the ones that govern the use in cases such as (3), in which the verb forms are independent clausal predicates. This is something that will also have to be taken into consideration in the next steps of the study. Cf. also Section [4]. 
nopmumb pf тесто!

'So you think I don't know who could do such a dirty trick - spoil the dough!' (ParaSol. Ostrovskij, KZs)

b. BELARUSIAN
(...) я не ведаю, Хто мог зрабіu̧ь ${ }^{\mathrm{PF}}$ такую подласць - сапсавац̧ь ${ }^{\mathrm{PF}}$ цеста?

c. UKRAINIAN

(...) я не знаю, Хто міг вчинити ${ }^{\mathrm{PF}}$ таку підлоту - зіпсувати ${ }^{\mathrm{PF}}$ тісто!

d. UPPER SORBIAN

(...) zo njewěm, štó móhł tajke njedočinštwo zwotaćpf - mi cesto ska$z y c ́$ !PF

e. SLOVAK

f. $\mathrm{CZECH}$
(...) že neviem, kto mohol spravit ${ }^{p f}$ také svinstvo, kto pokazil cesto!

(...) že já nevím, kdo mohl udělat ${ }^{\text {pf }}$ takovou ohavnost a zkazit ${ }^{\text {pf }}$ těsto?

g. SLOVENE

(...) da ne vem, kdo je bil zmožen napravitipf tako malopridnost - pokvaritipf $^{\text {pr }}$ testo!

In $\mathrm{BG}, \mathrm{SR}, \mathrm{HR}$, and $\mathrm{MK}$, a da-construction is used.

(5)

a. BULGARIAN

b. SERBIAN

(...) кой е могъл да извърши ${ }^{\mathrm{PF}}$ такава мръсотия, да развали ${ }^{\mathrm{PF}}$ тестото?

(...) da ja ne znam ko je mogao da učini ${ }^{p f}$ takvu podlost - da pokvaripf testo.

c. CROATIAN

(...) da ja ne znam tko je mogao da učinipf takovu podlost - da pokvaripf tijesto.

d. MACEDONIAN

(...) кој можел да направи ${ }^{\mathrm{PF}}$ таква подлост - да го расипе $e^{\mathrm{PF}}$ тестото!

As we can see, PF is used in both cases in all the languages in question.

I started my survey of aspect use in Slavic infinitives (and da-constructions) by isolating all non-negated ${ }^{6}$ infinitives in the Russian (original) version of Ostrovskij's Kak zakaljalas'stal' in ParaSol. In the initial survey, where the infinitives investigated may refer to any one of Vendler's (1957) situation types, the share of IPF infinitives is more than ten percentage points lower than that for imperatives: $49 \%$, as opposed to $60 \%$ for imperatives. When only telic predicates are taken into account, and when instances of нельзя + infinitive are excluded (together with не + infinitive) the share is even lower: $15 \%$. As regards Croatian, which for imperat-

\footnotetext{
${ }^{6}$ I excluded occurrences of $\mathrm{He}+$ infinitive. Cases in which only the matrix predicate is negated are included, as well as (some very few) instances of нельзя + infinitive.
} 
ives finds itself in the middle continuum of languages, using IPF in $45 \%$ of the cases investigated in Alvestad (2013), PF is used in more than $85 \%$ of the non-negated infinitives. PF is also used in approximately $85 \%$ of the cases in which a RU infinitive is translated with $d a+$ a present tense form. In other words, the use of aspect in the infinitive (and the da-construction, as the case may be) thus far seems to be almost identical in the East-Slavic languages, represented by RU, and the middle continuum of languages, represented by HR: IPF is used in only $15 \%$ of the cases in both languages, when only non-negated telic predicates are taken into consideration. $^{7}$

Based on these findings the following questions arise. РRовLем 2:

a. Under what circumstances is IPF used in telic predicates in the infinitive (and corresponding da-constructions) in the various Slavic languages?

b. Are the differences in aspect use between infinitives and imperatives due to the fact that infinitives can occur both with and without the modal force of necessity, ${ }^{8}$ whereas imperatives have the modal force of necessity? ${ }^{9}$

c. How is aspect used in infinitives when they do not have modal force ${ }^{10}$

d. How is aspect used in infinitives when they do have modal force?

I take it that the meaning of the Slavic PF is the inclusion of the event time in the reference time $(e \subset t)$, cf. e.g. Klein (1995). The meaning of the Slavic IPF is an underspecified temporal overlap relation between the event time and the reference time $(e \circ t)$. I ascribe the differences in aspect use to differences in how the individual languages resolve cases of aspectual competition. In cases of aspectual competition, both aspects can be used without significant changes in meaning. This can only occur in telic predicates, which is why I exclude states and activities from the study. When the unmarked IPF is aspectually neutralized, IPF has a perfective meaning. This use of IPF, in past tense indicatives in particular, is referred to in the literature as general-factual. Grønn (2004) refers to two main types of this interpretation as the existential and the presuppositional. Since imperatives are not

\footnotetext{
${ }^{7}$ As far as the share of infinitives versus $d a$-constructions (i.e. $d a+a$ present tense verb form) in HR is concerned, the numbers based on Ostrovskij's Kak zakaljalas' stal' in the ParaSol corpus are as follows. When a RU infinitive is translated into HR with either an infinitive or a da-construction, it is translated with an infinitive in just approximately $36 \%$ of the cases. (Occasionally, RU infinitives are translated into HR with nouns, or past or present tense verb forms without $d a$.)

${ }^{8}$ In (1), (2) and (3) the infinitives have the modal force of necessity, while in (4) they have the modal force of possibility. The matrix predicates in (1) and (2) are надо '[it is] necessary' and its equivalents and in (3) the infinitives function as imperatives. In (4), on the other hand, the matrix predicates are moz 'could' and its equivalents.

${ }^{9}$ Following Kaufmann (2012), imperatives are taken to have the modal force of necessity.

${ }^{10}$ The two occurrences of nоджигать 'set fire to' in (6) are both examples in which the infinitive does not have modal force.
} 
associated with facts, Alvestad (2013) follows Iatridou (2000) and Grønn (2008) in referring to IPF in such cases as fake. ${ }^{11,12}$ This term will be applied in the present account of infinitives too.

As far as imperatives are concerned, Alvestad (2013) follows Kaufmann's (2012) analysis and assumes that they are modals. Then, according to standard assumptions about the accessibility of antecedents, in Discourse Representation Theory (DRT) (Kamp 1981), for example, the event referent of one imperative VP is inaccessible to the event referent of another imperative VP. Alvestad (2013) therefore argues that in imperatives, we typically do not have event token anaphora, but event type anaphora, and that event type anaphora is sufficient to trigger the presuppositional type fake IPF in Slavic. The discourse referents of event types - predicates - are not subject to the same constraints as eventive discourse referents. This is an issue that will have to be considered if the presuppositional type fake IPF occurs in the infinitive and if infinitives are modal, as claimed by, for example, Wurmbrand (2014).

Now two questions arise. First, do we find fake IPFs in the infinitive? The answer to this question is, probably, yes. Consider the Russian example (6) below.

Оставлять немцам этот склад, конечно, нельзя ... Я считаю, нужно его сжечь. И сейчас же, чтобы к утру все было готово. Только поджигать ірf то опасно: сарай стоит на краю города среди бедняцких дворов. (...) Стружков шевельнулся: - За... за... чем... поджигать ? $^{\mathrm{IPF}}$

"'We are not going to leave the shed to the Germans; in my opinion we ought to burn it down, and at once, so as to have it over and done with by morning. To just set fire to it is dangerous: the fire might spread to the surrounding cottages. (...)" Stružkov stirred in his chair. "Why... why... why set fire to it?"' (ParaSol. Ostrovskij, Kzs)

In the literature the existential type fake IPF is also referred to as the naming of the action function of IPF, cf. e.g. Forsyth (1970). I therefore suggest that in (6), the first occurrence of IPF podžigat' 'set fire to' is existential, and that the second occurrence of IPF podžigat' is a presuppositional fake IPF, anaphoric to the first, existential type. ${ }^{13}$ (The underlining in the example signifies presupposition/anaphora.) The next problem I will seek to solve is the following. Problem 2-continued: (e) What type of fake IPF is most widespread in the infinitive - the existential type,

\footnotetext{
${ }^{11}$ For further details and examples the reader is referred to Grønn (2004) and Alvestad (2013).

${ }^{12}$ The IPF is fake in such cases in the sense that it is semantically perfective - it signifies that the event time is included in the reference time, $(e \subset t)$ - even though it is morphologically IPF.

${ }^{13}$ One of the reviewers suggests another possible interpretation-namely, that the first occurrence of IPF podžigat' 'set fire to' is anaphoric to the preceding PF сжкечь 'burn down'. Even though Alvestad (2013) shows that the anaphor and the antecedent may belong to distinct aspectual pairs, in this case the semantic difference may be a bit too big for us to argue that podžigat' and сжечь refer to the same event type. I therefore maintain the claim that the first occurrence of IPF podžigat' in (6) is a representative of the existential type fake IPF.
} 
the presuppositional type, or some other type? In past tense indicatives, the existential type is most frequent, cf. Grønn (2004). In imperatives, the presuppositional type is by far the most frequent type, cf. Alvestad (2013). Given the above, hypotheses with respect to Problem 2 are as follows. Hypothesis 2: (b) The differences in aspect use between the infinitive and the imperative are due to the fact that infinitives can, but need not, be embedded under modal predicates, whereas imperatives are necessity modals. (c) When an infinitive is embedded under a non-modal predicate, aspect is used as in past tense indicatives. (d) When an infinitive is embedded under a modal predicate, aspect is used as in the imperative. (e) When an infinitive is embedded under a non-modal predicate, the existential type fake IPF is most widespread. When an infinitive is embedded under a modal predicate, the presuppositional type fake IPF is most widespread.

The first occurrence of IPF podžigat' 'set fire to' in (6), which is an existential IPF, supports HYPOTHESIS 2. The second occurrence of IPF podžigat', however, is a presuppositional IPF. In order to test the hypotheses in 2, we need to look into more examples such as the one given in (6), which is part of what I will do in the abovementioned larger project. Hopefully, that work will give us the answer to at least some of the questions that have been raised throughout this paper.

\section{[4] CONCLUSION AND OUTLOOK}

I set out by raising the question of how aspect is used in the Slavic infinitive (and the corresponding da-constructions). I hypothesized that the East-West divide that has been observed for other verb forms and contexts of use can be observed in infinitives as well. Even though the present study is work in progress, we have seen that this may not be the case: Russian, which uses IPF in $60 \%$ of imperatives (cf. Alvestad (2013)), uses IPF in 15\% of infinitives, and the latter is also the case for Croatian, which uses IPF in $45 \%$ of imperatives. A larger database is needed to arrive at any firm conclusions regarding this question, but these initial results are all the same intriguing. These results and various examples led me to raise further questions, such as under what circumstances IPF is used in the infinitive (and the corresponding da-constructions), and whether the fake IPF does occur in the infinitive (and the corresponding da-constructions) and, if so, what type is most frequent - the existential, the presuppositional, or some other type. The next steps in the project will involve extending the database and deciding on how to classify the various matrix predicates involved, so as to see whether the kind of matrix has any impact on the use of aspect. ${ }^{14}$ Hopefully, these steps will eventu-

\footnotetext{
${ }^{14}$ As one of the reviewers correctly points out, the principles behind the use of aspect in these various constructions may not be uniform. This needs to be taken into consideration in a study of aspect use in infinitives in Slavic, alongside the possibility of cases in which a Slavic language $A$ has construction $x$ while Slavic language $B$ does not have this construction, and one of the aspects is compulsory in that particular construction. The latter point is particularly important when statistics are being used.
} 
ally give us a clear answer to Problem 1 and shed light on the questions comprising Problem 2. The project should shed some light on the long unresolved issue of infinitives, tense and time too.

\section{AC KN OWLE D GEMENTS}

Thanks are due to the two reviewers for highly valuable comments. An earlier version of this paper was published in Alvestad (2015).

ABBREVIATIONS

$\begin{array}{llll}\text { BG } & \text { Bulgarian } & \text { PL } & \text { Polish } \\ \text { BY } & \text { Belarusian } & \text { RU } & \text { Russian } \\ \text { CZ } & \text { Czech } & \text { SK } & \text { Slovak } \\ \text { HR } & \text { Croatian } & \text { SN } & \text { Slovene } \\ \text { IPF } & \text { imperfective } & \text { SR } & \text { Serbian } \\ \text { KZS } & \text { Kakzakaljalas' stal' } & \text { UK } & \text { Ukrainian } \\ \text { MK } & \text { Macedonian } & \text { US } & \text { Upper Sorbian } \\ \text { PF } & \text { perfective } & & \end{array}$

REFERENCES

Alvestad, Silje Susanne. 2013. - Beware of fakes! Fake imperfectives in the Slavic imperative. University of Oslo. $\mathrm{PhD}$ dissertation.

Alvestad, Silje Susanne. 2015. Aspect use in the Slavic infinitive (and subjunctive). In Kitajo Mitsushi (ed.), Aspektual'naja semanticheskaja zona: tipologija sistem $i$ scenarii diakhronicheskogo razvitija: Sbornik statej $v$ mezhdunarodnoj konferencii komissii po aspektologii mezhdunarodnogo komiteta slavistov, 7-14. Kyoto: Tanaka Print.

Benacchio, Rosanna. 2010. Vid i kategorija vežlivosti v slavjanskom imperative: sravnitel'nyj analizxi. Munich: Otto Sagner.

Dickey, Stephen M. 2000. Parameters of Slavic aspect: A cognitive approach. Stanford, California: CSLI Publications.

Dobrušina, Nina. 2012. Infinitivnye konstrukcii s časticej BY. Russkij jazyk v naučnom osveščenii 24(2). 42-64.

Forsyth, James. 1970. A grammar of aspect: Usage and meaning in the Russian verb. Cambridge: Cambridge University Press.

Fortuin, Egbert L. J. 2000. Polysemy or monosemy: Interpretation of the imperative and dative-infinitve construction in Russian. Dissertation series. Amsterdam: ICLC. 
Fortuin, Egbert L. J. 2007. Modality and aspect: interaction of constructional meaning and aspectual meaning in the dative-infinitive construction in Russian. Russian Linguistics 31. 201-230.

Galton, Herbert. 1976. The main functions of the Slavic verbal aspect. Skopje: Macedonian Academy of Sciences and Arts.

Grønn, Atle. 2004. The semantics and pragmatics of the Russian factual imperfective. University of Oslo. Doctoral dissertation.

Grønn, Atle. 2008. Imperfectivity and complete events. In F. Josephson \& I. Söhrman (eds.), Interdependence of diachronic and synchronic analyses, 149-165. Amsterdam: John Benjamins.

Han, Chung-hye. 1998. The structure and interpretation of imperatives: Mood and force in universal grammar. University of Pennsylvania. PhD dissertation.

Iatridou, Sabine. 2000. The grammatical ingredients of counterfactuality. Linguistic Inquiry 31(2). 231-270.

Israeli, Alina. 2013. Dative-infinitive constructions in Russian: Taxonomy and semantics. In Irina Kor Chahine (ed.), Current studies in Slavic linguistics, 199224. Amsterdam: John Benjamins.

Israeli, Alina. 2014. Dative-infinitive BY constructions in Russian: Taxonomy and semantics. In Jacek Witkós \& Sylwester Jaworski (eds.), New insights into Slavic linguistics, 141-159. Frankfurt am Main: Peter Lang.

Kamp, Hans. 1981. A theory of truth and semantic representation. In J. Groenendijk, T. Janssen \& M. Stokhof (eds.), Formal methods in the study of language, 277-322. Amsterdam: Mathematisch Centrum.

Kaufmann, Magdalena. 2012. Interpreting imperatives. Dordrecht: Springer.

Klein, Wolfgang. 1995. A time-relational analysis of Russian aspect. Language 71(4). 669-695.

Mišeska-Tomić, Olga. 2006. Infinitives and subjunctives. In Balkan sprachbund morpho-syntactic features, 413-657. Dordrecht: Springer.

Prokofeva, R. 1959. How the steel was tempered. Moscow: Foreign languages publishing house. Translation of Nikolaj Ostrovskij. 1936. Kak zakaljalas'stal'.

Stowell, Tim. 1982. The tense of infinitives. Linguistic Inquiry 13(3). 561-570.

Todorović, Neda. 2012. The indicative and subjunctive da-complements in Serbian: A syntactic-semantic approach. University of Illinois at Chicago. PhD dissertation. 
Vendler, Zeno. 1957. Verbs and times. The Philosophical Review 66(2). 143-160.

von Waldenfels, Ruprecht. 2006. Compiling a parallel corpus of Slavic languages. text strategies, tools and the question of lemmatization in alignment. In B. Bremer, V. Zdanova \& R. Zimny (eds.), Beiträge der europäischen slavistischen Linguistik (POLYSLAV) 9, 123-138. Munich: Otto Sagner.

von Waldenfels, Ruprecht. 2012. Aspect in the imperative across Slavic: A corpusdriven pilot study. Oslo Studies in Language 4(1). 141-154.

Wiemer, Björn. 2001. Aspect choice in non-declarative and modalized utterances as extensions from assertive domains. (lexical semantics, scopes, and categorial distinctions in Russian and Polish). In H. Bartels, N. Störmer, \& E. Walusiak (eds.), Untersuchungen zur Morfologie und Syntax im Slavischen, 195-221. Oldenburg: BIS-Verlag.

Wurmbrand, Susi. 2014. Tense and aspect in English infinitives. Linguistic Inquiry 45(3). 403-447. 